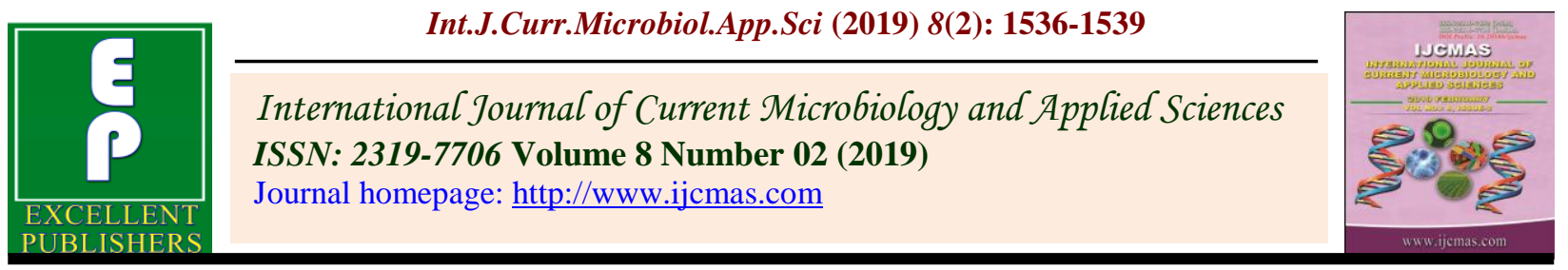

Original Research Article

https://doi.org/10.20546/ijcmas.2019.802.179

\title{
Standardization of Softwood Grafting in Tamarind (Tamarindus indica L.)
}

\author{
R. Praveenakumar ${ }^{*}$, R. Vasantha Kumari, B.G. Hanumantharaya and C. Suneetha \\ Department of Horticulture, GKVK, University of Agricultural Sciences, \\ Bangalore-560065, India
}

*Corresponding author

\section{Keywords \\ Tamarind, \\ Softwood grafting, Months, Success and survival \\ Article Info \\ Accepted: \\ 12 January 2019 \\ Available Online: \\ 10 February 2019}

\section{A B S T R A C T}

Standardization of Softwood Grafting in Tamarind was carried out at the Department of Horticulture, GKVK, UAS, Bangalore. The broad objectives of the investigation are to study the success and survival per cent of softwood grafting in Tamarind using only Tamarindus indica as rootstock under Bangalore condition over the months (February to May) in different growing condition. A significant effect was observed with different treatment (Months of grafting), sub treatment (Growing conditions) on the observation recorded on softwood grafts of Tamarind The softwood grafting success and survival rate were recorded highest in T4 (M2C1: March + low cost polyhouse) with $96.66 \%$ and $96.68 \%$, respectively. Softwood grafting was performed well under March + low cost polyhouse condition.

\section{Introduction}

Tamarind (Tamarindus indica L.), a member of subfamily Caesalpiniaceae of family Fabaceae, is an underutilized fruit and widely distributed throughout tropic and sub-tropics as stray plantation or avenue. It is a source of timber, fruits, seeds, fodder, medicinal extracts and has potential of industrial use (Dwivedi et al., 1990, 1992). It is highly heterozygous, cross-pollinated fruit crop and as such seedlings exhibit a wide range of variations, which aids in the selection of the superior desirable genotypes. Due to cross pollination and Predomination practice of seed propagation, there is immense opportunity to locate elite trees having desirable horticultural traits, which needs to be conserved and exploited (Keskar et al., 1989; Pathak et al., 1992 and Karale et al., 1999). Despite its varied advantages, it could not attract suitable scientific attention towards its propagation. True-to-the-type propagules could be multiplied from elite trees that produce good quality fruits only by asexual methods. Of various propagation methods, grafting and budding are of paramount importance in tropical and subtropical fruit trees as they result in high success and field establishment. The time and method are considered to be the most vital factor that determines the success and establishment of the grafts. Systematic information in this regard is scanty particularly under harsh semi- 
arid ecosystem for tamarind. Therefore, the present investigation was undertaken to standardize method and time of propagation and different conditions of grafting in tamarind under Eastern dry zone of Karnataka.

\section{Materials and Methods}

The experiment was conducted at Division of Horticulture, University of Agricultural Sciences, Bengaluru during 2017 (February to May) It is situated at an elevation of $830 \mathrm{~m}$ above the mean sea level, at $121^{\circ} 58^{\prime}$ north latitude and $77^{\circ} 35^{\prime}$ east longitude. The annual mean relative humidity of location is 85.6 per cent. The minimum and maximum temperature in a year ranges between $17.4^{\circ} \mathrm{C}$ and $37^{\circ} \mathrm{C}$ respectively. The average rainfall was about $930 \mathrm{~mm}$. The experiments were carried out with the main objectives of studies on softwood grafting techniques using low cost poly house, shade net and open field condition facilities. To raise the nursery, fresh seeds were sown in a seed pan for germination. When seedlings attained four leaf stages they were transplanted to polyethylene bags containing a potting mixture of red sandy loam soil, sand and farm yard manure in the ratio of $3: 1: 1$, respectively. The seedlings were grown for one year and softwood grafting during four different months softwood grafting over the year was done with scion procured from 10 years old healthy tamarind tree. The vegetative growth such as sprouting and leaf emergence of graft success and survival per cent was recorded at 60 and 90 days after softwood grafting of tamarind.

\section{Results and Discussion}

The highest of graft success per cent (85.55, 85.12) was found under the March (M2), low cost polyhouse (C1), respectively (Table 1). Could also be correlated to higher cell activity and active growth of both stock and scion in the prevailing favorable climatic conditions. The same results were recorded in jamun by Ghojage et al., (2011). The environmental conditions for low cost polyhouse grafts can be readily controlled, thereby permitting greater reliability of grafting over long period compared to open field grafting operation (Hartman and Kester, 1979).

Table.1 Influence of the months of grafting, growing condition and their interaction on Graft success and survival (\%) of Tamarind after 60 and 90 days of grafts

\begin{tabular}{|c|c|c|}
\hline Treatments & Graft success (\%) & Graft Survival (\%) \\
\hline \multicolumn{3}{|c|}{ MONTHS (M) } \\
\hline$M_{1}$ - February & 78.88 & 71.11 \\
\hline $\mathbf{M}_{2}$-March & 85.55 & 77.77 \\
\hline $\mathbf{M}_{3}$-April & 76.66 & 62.22 \\
\hline M4-May & 58.88 & 41.11 \\
\hline$F$ test $(p \leq 0.05)$ & $*$ & $*$ \\
\hline S.Em \pm & 04.05 & 03.91 \\
\hline C.D at $5 \%$ & 12.13 & 13.92 \\
\hline \multicolumn{3}{|c|}{ CONDITION(C) } \\
\hline $\begin{array}{c}C_{1} \text {-Low cost } \\
\text { polyhouse }\end{array}$ & 85.12 & 76.66 \\
\hline $\mathrm{C}_{2^{-}}$Open field & 62.65 & 44.16 \\
\hline
\end{tabular}




\begin{tabular}{|c|c|c|}
\hline $\mathrm{C}_{3^{-}}$-Shade net & 75.35 & 68.33 \\
\hline$F$ test $(p \leq 0.05)$ & * & * \\
\hline S.Em \pm & 01.31 & 02.17 \\
\hline C.D at 5\% & 03.90 & 06.58 \\
\hline \multicolumn{3}{|c|}{ INTERACTION $(\mathrm{M} \times \mathrm{C})$} \\
\hline $\mathbf{M}_{1} \mathbf{C}_{1}$ & 90.02 & 80.23 \\
\hline $\mathbf{M}_{1} \mathbf{C}_{2}$ & 63.33 & 60.32 \\
\hline $\mathbf{M}_{1} \mathbf{C}_{3}$ & 83.33 & 73.35 \\
\hline$M_{2} C_{1}$ & 96.66 & 96.68 \\
\hline $\mathrm{M}_{2} \mathrm{C}_{2}$ & 70.56 & 50.85 \\
\hline $\mathbf{M}_{2} \mathbf{C}_{3}$ & 90.78 & 86.65 \\
\hline $\mathrm{M}_{3} \mathrm{C}_{1}$ & 83.3 & 76.66 \\
\hline $\mathrm{M}_{3} \mathrm{C}_{2}$ & 70.00 & 40.32 \\
\hline $\mathrm{M}_{3} \mathrm{C}_{3}$ & 76.66 & 70.89 \\
\hline$M_{4} C_{1}$ & 70.78 & 53.34 \\
\hline $\mathbf{M}_{4} \mathbf{C}_{2}$ & 50.66 & 26.66 \\
\hline $\mathrm{M}_{4} \mathrm{C}_{3}$ & 56.66 & 43.39 \\
\hline$F$ test $(p \leq 0.05)$ & * & * \\
\hline S.Em \pm & 4.54 & 03.15 \\
\hline C.D at 5\% & 15.52 & 12.35 \\
\hline
\end{tabular}

*Significant

T1- M1C1: February + Low cost polyhouse

T2- M1C2: February + open field

T3- M1C3: February + Shadenet

T4- M2C1: March + Low cost polyhouse

T5- M2C2: March + Open field

T6- M2C3: March +Shadenet
T7-M3C1: April + Low cost Polyhouse T8-M3C2: April + Open field T9-M3C3: April+Shadenet T10-M4C1: May + Low cost Polyhouse T11-M4C2: May + Open field T12- M4C3: May + Shadenet
Highest graft survival per cent $(77.77,76.66)$ was found in March month (M2), low cost polyhouse $(\mathrm{C} 1)$ respectively (Table 1$)$. The highest graft success in March under low cost polyhouse might be due the favorable climatic condition in term of high temperature and high relative humidity values. Similar opinion was also expressed by shinde et al., (2011) in jamun. In Tamarind, days taken for graft success and survival percentage showed superior in low cost polyhouse condition under the March month, has compared to other to conditions.

\section{References}

Dwivedi, K., Ali, Wahid and Pathak, R.K. 1990. Effect of sodicity on growth and mineral content of tamarind (Tamarindus indica L.). Ann. Agril. Res. 17: 447-49.

Ghojage, A. H., Swamy, G. S. K., Kanamadi, V. C., Jagdeesh, R. C., Kumar, P. C., Patil, P. And Reddy, B. S., 2011, Effect of season on softwood grafting in Jamun (Syzygium cumini, Skeels.) Acta Hort, 890.

Hartamann, H. T. And Kester, D. E., 1989, Plant Propagation Principles and practices fifth Edn., Prentice Hall Ltd., pp. 360-363.

Karale, A.R., Wagh, A.P., Pawar, B.G. and More, T.A. 1999. Association of fruit characters in tamarind. $J$. Maharashtra Agril. Univ. 24: 319-20.

Keskar, B.G., Karale, A.R., Dhawale, B.C. 
and Chaudhary, K.G. 1989. Shinde S. B, Saiyad M. Y, Jadav R. G, Improvement of tamarind by selection. Maharashtra J. Hort. 4: 121-24. Chavda J. C. 2011, Effect of time on softwood grafting success and survival

Pathak, R.K., Ojha, C.M. and Dwivedi, R. of jamun grafts (Syzygium cimini 1992. Adopt patch budding for Skeel). Intl. J. Agril Sci., 967; 7: 83quicker multiplication in tamarind. 85 . Indian Hort. 36: 17.

\section{How to cite this article:}

Praveenakumar, R., R. Vasantha Kumari, B.G. Hanumantharaya and Suneetha, C. 2019. Standardization of Softwood Grafting in Tamarind (Tamarindus indica L.). Int.J.Curr.Microbiol.App.Sci. 8(02): 1536-1539. doi: https://doi.org/10.20546/ijcmas.2019.802.179 